\title{
El cinco inflamatorio abdominal
}

\section{Inflammatory abdominal five}

\author{
Francisco Medina Romero ${ }^{1}$ Tania Rodríguez Méndez ${ }^{1}$ María Fernanda Lara Martínez ${ }^{1}$ \\ ${ }^{1}$ Complejo Hospitalario Universitario de Canarias (CHUC), La Laguna, \\ Santa Cruz de Tenerife, Islas Canarias, España \\ Rev Argent Radiol 2022;85(Suppl S1):S23. \\ Address for correspondence Francisco Medina Romero, Médico \\ Adjunto, Complejo Hospitalario Universitario de Canarias (CHUC), \\ La Laguna, Santa Cruz de Tenerife, Islas Canarias, España, \\ (e-mail: drfranciscomedina@gmail.com).
}

La gammagrafía de leucocitos marcados con Tc99m-HMPAO sirve para la valoración de la actividad de la enfermedad inflamatoria intestinal. Nuestro paciente presentaba sospecha de afectación en un segmento de íleon terminal, traducida en un engrosamiento mural con realce tras la administración de contraste en la tomografía computada e hiperintensidad en las secuencias potenciadas en $\mathrm{T} 2$ en la resonancia magnética (RM) (-Fig. 1).

La intensa migración leucocitaria patológica que mostraba nuestro paciente en las imágenes tardías y en el SPECT adquirieron forma de cinco ( - Figs. 2A y B).

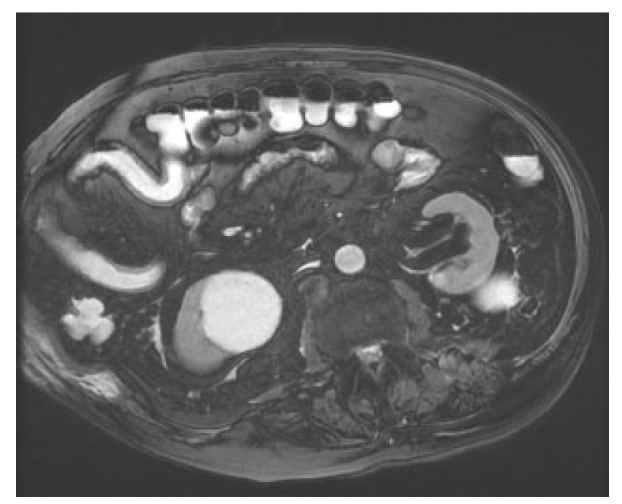

Fig. 1 RM axial de secuencia potenciada en T2, saturación grasa.
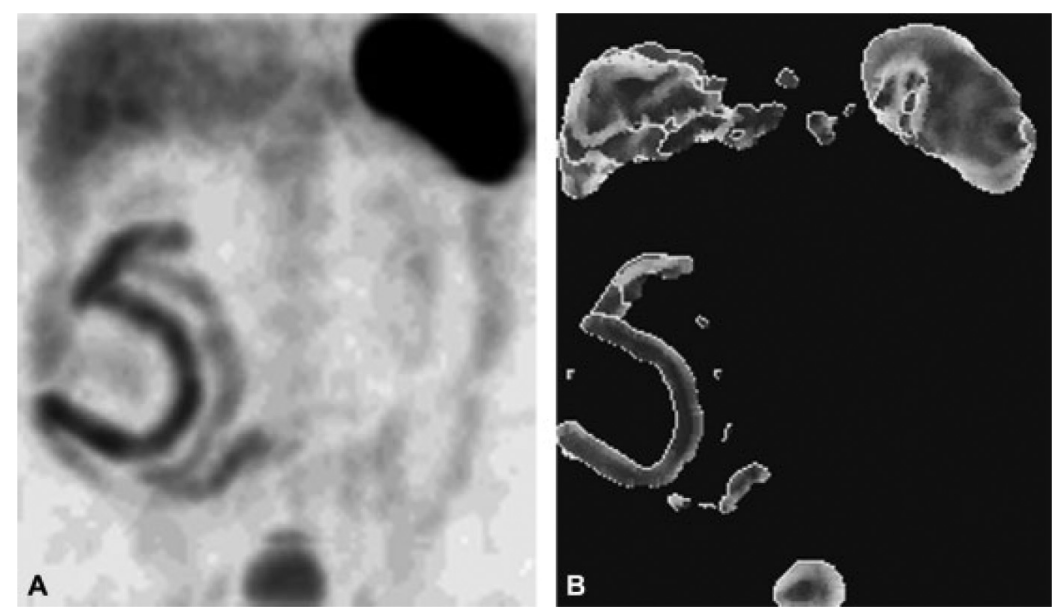

Fig. 2 (A and B) Reconstrucciones de máxima intensidad de proyección (MIP) y MIP de superficie del estudio SPECT de leucocitos marcados.

received

August 30, 2018

accepted

October 29, 2018

published online

January 14, 2019
DOI https://doi.org/

10.1055/s-0038-1676309.

ISSN 1852-9992.
(C) 2019. Asociación Civil Sociedad Argentina de Radiología and Federacion Argentina de Asociaciones de Radiología, Diagnóstico por Imágenes y Terapia Radiante. All rights reserved.

This is an open access article published by Thieme under the terms of the Creative Commons Attribution-NonDerivative-NonCommercial-License, permitting copying and reproduction so long as the original work is given appropriate credit. Contents may not be used for commercial purposes, or adapted, remixed, transformed or built upon. (https://creativecommons.org/ licenses/by-nc-nd/4.0/)

Thieme Revinter Publicações Ltda., Rua do Matoso 170, Rio de Janeiro, RJ, CEP 20270-135, Brazil 